5. Янченко, Ю. В. Художньо-естетична своєрідність казок Оскара Уайльда. Наукові записки Харківського національного педагогічного університету ім. Г.С. Сковороди. Серія: Літературознавство. 2009. Вип. 3 (1). С. 74-80. URL: http://nbuv.gov.ua/UJRN/Nzl_2009_3\%281\% 29 _10. (Дата звернення 10 листопада 2020 р.).

DOI https://doi.org/10.30525/978-9934-26-004-9-56

\title{
СИМВОЛІЧНИЙ жИВОПИС МИХАЙЛА САПОЖНИКОВА (1871 - 1937). СЬОГОДЕННІ ПРАКТИКИ ДОСЛІДЖЕННЯ ТА ПРЕЗЕНТАЦЇ̈
}

\author{
Несмачний С. М. \\ аспірант \\ Національної академії керівних кадрів культури і мистецтв \\ м. Київ, Украӥна, \\ заступник директора з наукової роботи \\ Комунального закладу культури «Дніпропетровський художній музей» \\ Дніпропетровської обласної ради» \\ м. Дніпро, Україна
}

Перша чверть XX століття - динамічна, складна та драматична фаза розвитку вітчизняної культури і образотворчого мистецтва зокрема.

На початку XX століття в Україні надзвичайно активізувалось культурне життя - це час небаченого злету інтелектуальної думки, виникнення і поступу розмаїття естетичних та філософських концепцій, бурхливого розвитку нових мистецьких напрямів й художніх практик та появи плеяди яскравих творчих індивідуальностей $[0,86]$.

Співіснування різноспрямованих течій в образотворчому мистецтві характерна ознака того часу. Тоді ще активно діють пересувні художні виставки, учасники яких відстоюють принципи демократичного реалізму, і в цей же час ряд українських художників освоюють сучасні на той момент європейські мистецькі напрями - від імпресіоністичного творчого методу до найактуальніших модерних та авангардних художніх практик.

Однією 3 ключових літературно-мистецьких складових тогочасної культури був символізм. Саме 3 ідеями та естетикою символізму в образотворчому мистецтві пов'язана визначальна частина творчого доробку Михайла Сапожникова (1871 - 1937), який жив та працював в Катеринославі-Дніпропетровську в першій третині XX століття. 
Переважна більшість мистецького спадку живописця (більше 250 живописних та графічних робіт) зберігається у Дніпропетровському художньому музеї. До музейної збірки твори М.I. Сапожникова потрапили наприкінці 1960-х років, але для експонування та дослідження вони стали доступні тільки за часів Незалежності України, після проведення необхідних реставраційних робіт [0, 19]. Колекція творів Сапожникова може дати достатньо цілісне уявлення про його мистецькі уподобання та пошуки, адже хронологічно вона охоплює майже весь творчий шлях майстра: від студентських натурних постановок часів навчання в Імператорській Академії мистецтв (1890-х рр.) до пейзажних замальовок-настроїв останніх років життя (1930-ті рр.).

Особливий інтерес у дослідника можуть викликати дві серії символічних картини та відповідний допоміжний матеріал, який складається 3 натурних етюдів та ескізів. Серії, що об'єднують по 12 картин (Серія № 1 «Примари», 1906 - 1916; Серія № 2, 1917 - 1924), значно відрізняються одна від одної за художньою мовою, що є цілком природно, зважаючи на те, що мистецтво символізму неможливо обмежити якимись стилістичними рамками.

В картинах серій, що були створені під враженням від революційних шоків 1905 - 1917 років, Першої Світової та Громадянської війн, Михайло Сапожников у художніх образах-символах прагне віддзеркалити як теми «одвічних» філософських пошуків, так і актуальні погляди свого часу. У фокусі уваги Михайла Сапожникова - діалектично пов'язані всесвіт і людина. Конкретні образи, події та вся історія людства розглядаються автором у площині глобальній - космічній. Він художньо осмислює вічні категорії добра і зла, світла і мороку, правди і кривди, розмірковує про життя та смерть, початок і кінець, вічність і тлінність.

Сприйняття творів художника, на думку самого автора, має бути активним, і в глядачеві він скоріше намагається знайти співрозмовника та співавтора, ніж пасивного спостерігача [0]. Відповідно, можливе зовсім різне трактування символічних образів, враховуючи ступінь культурного або освітнього розвитку «співрозмовника». Передбачаючи те, що його думки та ідеї не просто буде зрозуміти відповідно саме до авторського задуму, митець, окрім оригінальної назви, дає кожній картині в серії номер (а значить - i конкретне експозиційне місце), а також підбирає до кожного твору відповідний «коментар» з Біблії.

Мистецький доробок Михайла Сапожникова видається нам винятковим в історії українського мистецтва першої чверті XX століття. Разом $з$ тим, на жаль, його ім'я та його живопис, відомі здебільшого вузькому колу знавців. 
У новітньому часі (2010-ті pр.) першими кроками на шляху дослідження та репрезентації творчого доробку унікального катеринославського художника стало включення низки його робіт до основної експозиції Дніпропетровського художнього музею [0]. До експозиційного блоку «Модерн. Авангард. Символізм», після реекспозиції 2018 року, увійшли десять творів майстра (дев'ять з яких презентують символістську частину його мистецького спадку), що певною мірою сприяло інтегруванню його імені та творчого доробку до лінії розвитку вітчизняного мистецтва першої чверті XX ст.

Визначними також стали дві мистецькі події, що відбулися навесні 2019 року у Дніпропетровському художньому музеї, а саме: презентація видання «Світ символів Михайла Сапожникова» (автор - В.В. Кулічихін) та відкриття музейного виставкового проекту» Від Задуму до Втілення. Світ символів Михайла Сапожникова» (куратори - С.М. Несмачний та О.С. Щербина).

Образотворче видання «Світ символів Михайла Сапожникова», де в науково-популярній формі викладені основні факти біографії митця та проілюстровано головні живописні та графічні твори майстра, стало підсумком дослідницької роботи В.В. Кулічихіна, який протягом довгого часу (працюючи на посадах наукового співробітника, головного зберігача та директора музею) вивчав матеріали щодо біографії та творчої спадщини М.I. Сапожникова. На жаль, передчасна смерть автора у 2016 році не дозволила досліднику побачити працю свого життя у завершеному вигляді, тому закінчувати справу довелось його колегам, науковим співробітникам музею.

Виставковий проект »Від Задуму до Втілення. Світ Символів Михайла Сапожникова» теж став непересічною подією, адже виставку такого формату зали Дніпропетровського художнього музеї ще не бачили. В експозиції було об'єднано вибрані твори 3 двох серій символічних картин з ескізами цих робіт, натурними замальовками та етюдами (що зазвичай позбавлені експозиційної уваги), а також «сторінки» 3 книги Володимира Кулічихіна - смислові «пояснення» до кожної картини та тонко підібрані рядки 3 поезій відомих авторів «срібного віку». Виставковий проект »Від Задуму до Втілення. Світ Символів Михайла Сапожникова» - це виставка-дослідження, »своєрідна спроба відслідкувати шлях митця від ідеї до художнього втілення та показати шлях дослідника від твору до розкриття і потрактування смислу художнього символу» [0]. Кожне полотно розглядається як самостійна робота, до створення якої веде певний, зазвичай невідомий глядачеві, ланцюжок художніх пошуків та узагальнень. Експозиція виставки надала широке поле для глядацької інтерпретації, адже «далеко не завжди 
достеменно відомо, чи то певний етюд з натури слугував підготовчою працею до картини, чи він - лиш поштовх, зерно з якого виростає символічна композиція» [0].

Вихід в світ образотворчого видання «Світ символів Михайла Сапожникова» та презентація виставкового проекту »Від Задуму до Втілення. Світ Символів Михайла Сапожникова», ставши, безумовно, непересічними культурними подіями, опрявнили перші кроки на шляху усвідомлення творчого спадку художника, який потребує подальшого вивчення в контексті виявлення стильових особливостей, генези та ідейно-філософських засад символістської творчості митця та осмислення символізму як мистецького напряму в українському художньому житті першої третини XX століття. Комплексне наукове мистецтвознавче дослідження, слугуватиме запорукою того, що, ім'я Михайла Сапожникова міцно увійде до широкого наукового обігу, а постать посяде достойне місце в колі майстрів українського образотворчого мистецтва.

\section{Література:}

1. Історія українського мистецтва: у 5-ти т. НАН України ІМФЕ ім. М.Т. Рильського, голов. ред. Г. Скрипник. Київ, 2007. Т. 5: Мистецтво ХХ століття. $1048 \mathrm{c}$.

2. Криволапов М.О. Українське мистецтво XX століття в художній критиці. Практика. Теорія. Історія. Київ : КИТ, 2006. 796 с.

3. Крючкова В.А. Символизм в изобразительном искусстве: Франция и Бельгия, 1870-1900. Москва : Изобразительное искусство, 1994. 272 с.

4. Куличихин В.В. Мир символов Михаила Сапожникова. Днепр : Литограф, 2018. 176 с.

5. Несмачний С.М. «Модерн. Авангард. Символізм» - нова зала музейної експозиції. Дніпропетровський художній музей : офіц. веб-сайт. URL: http://artmuseum.dp.ua/?p=7726 (дата звернення: 20.11.2020).

6. Сапожников М. И. О символическом творчестве в искусстве. Аргонавты. Журнал искусств. Екатеринослав, 1918. № 1. С. 23-24.

7. Щербина О.С. Від Задуму до Втілення. Світ Символів Михайла Сапожникова. Дніпропетровський художній музей : офіц. веб-сайт. URL: http://artmuseum.dp.ua/?p=8174 (дата звернення: 20.11.2020). 